\title{
Association study of the trinucleotide repeat polymorphism within SMARCA2 and schizophrenia
}

\author{
Sarojini Sengupta1,2, Lan Xiong3,4, Ferid Fathalli2,4, Chawki Benkelfat ${ }^{3}$, \\ Karim Tabbane ${ }^{5}$, Zoltan Danics ${ }^{6}$, Alain Labelle ${ }^{7}$, Samarthji Lal2,3, Marie- \\ Odile Krebs', Guy Rouleau ${ }^{4}$ and Ridha Joober*1,2,3
}

\begin{abstract}
Address: ${ }^{1}$ Department of Human Genetics, McGill University, Montreal, Canada, ${ }^{2}$ Douglas Hospital Research Centre, Montreal, Canada, ${ }^{3}$ Department of Psychiatry, McGill University, Montreal, Canada, ${ }^{4}$ Center for the Study of Brain Diseases, Notre Dame Hospital, Montreal, Canada, ${ }^{5}$ Department of Psychiatry, University of Tunis, Tunis, Tunisia, ${ }^{6}$ National Institute of Psychiatry, Budapest, Hungary, ${ }^{7}$ Department of Psychiatry, University of Ottawa, Ottawa, Canada and ${ }^{8}$ Service Hospitalo-Universitaire, Hôpital Sainte-Anne, Paris, France

Email: Sarojini Sengupta - sarojini.sengupta@douglas.mcgill.ca; Lan Xiong - lan.xiong@elf.mcgill.ca;

Ferid Fathalli - ferid.fathalli@douglas.mcgill.ca; Chawki Benkelfat - chawki.benkelfat@mcgill.ca; Karim Tabbane - k_tabbane@yahoo.fr; Zoltan Danics - zdanics@axelero.hu; Alain Labelle - alabelle@rohcg.on.ca; Samarthji Lal - samarthji.lal@douglas.mcgill.ca; Marie-

Odile Krebs - krebs@broca.inserm.fr; Guy Rouleau - guy.rouleau@mcgill.ca; Ridha Joober* - ridha.joober@douglas.mcgill.ca

* Corresponding author
\end{abstract}

Published: 03 June 2006

BMC Genetics 2006, 7:34 doi:10.1 186/147/-2156-7-34
Received: 02 january 2006

Accepted: 03 June 2006

This article is available from: http://www.biomedcentral.com/I47/-2/56/7/34

(c) 2006 Sengupta et al; licensee BioMed Central Ltd.

This is an Open Access article distributed under the terms of the Creative Commons Attribution License (http://creativecommons.org/licenses/by/2.0), which permits unrestricted use, distribution, and reproduction in any medium, provided the original work is properly cited.

\begin{abstract}
Background: Brahma (BRM) is a key component of the multisubunit SWI/SNF complex, a complex which uses the energy of ATP hydrolysis to remodel chromatin. BRM contains an Nterminal polyglutamine domain, encoded by a polymorphic trinucleotide (CAA/CAG) repeat, the only known polymorphism in the coding region of the gene (SMARCA2). We have examined the association of this polymorphism with schizophrenia in a family-based and case/control study. SMARCA2 was chosen as a candidate gene because of its specific role in developmental pathways, its high expression level in the brain and some evidence of its association with schizophrenia spectrum disorder from genome-wide linkage analysis.
\end{abstract}

Results: Family-based analysis with $28 \mathrm{I}$ complete and incomplete triads showed that there is no significant preferential transmission of any of the alleles to the affected offspring. Also, in the case/ control analysis, similar allele and genotype distributions were observed between affected cases ( $\mathrm{n}$ = 289) and unaffected controls $(n=273)$ in each of three Caucasian populations studied: French Canadian, Tunisian and other Caucasians of European origin.

Conclusion: Results from our family-based and case-control association study suggest that there is no association between the trinucleotide repeat polymorphism within SMARCA2 and schizophrenia.

\section{Background}

The SWI/SNF complex is a $2 \mathrm{MDa}$, multi-subunit complex that uses the energy of ATP hydrolysis to disrupt nucleosome structure thereby increasing accessibility of tran- scription factors to their specific sites on DNA and histones. It is well conserved, with homologous complexes isolated from yeast, Xenopus, Drosophila and mammals [1]. SWI/SNF complexes purified from mam- 
malian cell lines have been found to be heterologous with respect to their subunit composition, containing between 9-12 subunits [2]. However, each complex contains Brahma (BRM), a DNA-dependant ATPase, or the related protein BRG1. The precise subunit composition of the complex appears to confer functional specificity via protein-protein interactions with specific transcription factors. BRM has been shown to be specifically required for activation by the androgen receptor [3]. In addition, BRM and not BRG1, interacts specifically with CBF-1 and ICD22, two components of the Notch signalling pathway, a pathway that controls cell fate commitment in several developmental processes [4]. Studies in mice have shown that high levels of BRM, in comparison to levels of BRG1, are present in brain tissue of the animals [5].

BRM is encoded by the SMARCA2 gene. It is a member of the large, diverse SMARC (SWI/SNF-related, matrix-associated, actin-dependant regulator of chromatin) family. The only polymorphism within the encoding region of this gene is a stable, polymorphic trinucleotide repeat. We have carried out a case/control and family-based study to examine the association of this polymorphism with schizophrenia (SCZ).

Investigating SMARCA2 as a candidate gene for SCZ, is plausible for several reasons. First, genome-wide expression analysis of a post-mortem section of the dorsolateral prefrontal cortex of schizophrenia patients showed that SMARCA2 (also referred to as hSNFa) was upregulated 1.42-fold relative to non-affected controls [6]. Even though this upregulation of SMARCA2 has not been confirmed in other studies, several groups have demonstrated significant differences in mRNA levels in schizophrenic patients relative to controls. Gene expression profiles using post-mortem brain tissue (entorhinal cortex layer II stellate neurons) showed that $14 \%$ of the genes were upregulated while $9 \%$ were down-regulated more than twofold in the SCZ group relative to controls [7]. These results could be an indication that a global regulator of transcription may be involved in SCZ. BRM is one such global transcription regulator. BRM appears to be involved in the regulation of transcription (activation as well as repression) of a subset of genes. Genome-wide analysis, following deletion of SWI2 (the yeast homolog of BRM), showed that $1 \%$ of the 6,000 genes tested displayed more than a 3-fold change in mRNA levels, with some genes being up-regulated and others down-regulated $[8,9]$.

A second reason why an association between BRM and schizophrenia is plausible is that BRM appears to play an important role in cell development in general, and neuronal differentiation in particular and SCZ is believed to be a neurodevelopmental disorder [10]. Unlike BRG1, where levels are relatively constant in all cells, the cellular concentration of BRM increases during cell differentiation. Studies with neural cell cultures showed that BRM expression increased during differentiation from neural precursor cells to neural cells [11]. Kondo and Raff [12] provide evidence that the conversion of oligodendrocyte precursor cells to neural stem cells required the recruitment of BRM. Further, BRM has been shown to strongly associate with CBF-1 and ICD22, two components of the Notch signalling pathway which play a key role in cell fate commitment during development [4].

Finally studying BRM as a candidate gene is supported by some linkage studies. SMARCA2 is located on chromosome 9p22.3. Genome scan meta analysis indicated that region 9p22.3-21.1 demonstrated significant linkage ( $p<$ 0.01 ) with a schizoaffective-bipolar and bipolar-I disease model [13].

\section{Results and discussion}

BRM encapsulates several distinct domains including a polyglutamine domain, the DNA-dependant helicase domain and the bromodomain. The N-terminal polyglutamine domain is well conserved in mammals with

Table I: Summary of subjects used in the family-based study

\begin{tabular}{|c|c|c|c|c|c|c|}
\hline & \multicolumn{3}{|c|}{ No of families } & \multicolumn{3}{|c|}{ No of triads } \\
\hline & $\begin{array}{l}\text { Families with one } \\
\text { affected individual }\end{array}$ & $\begin{array}{l}\text { Families with more than } \\
\text { one affected individual }\end{array}$ & Total & Complete triad & Incomplete triad* & Total \\
\hline French Canadian & 41 & 0 & 41 & 13 & 28 & 41 \\
\hline Tunisian & 24 & 12 & 36 & 52 & 2 & 54 \\
\hline Other Caucasian of European origin-I & 58 & 1 & 59 & 28 & 35 & 63 \\
\hline Other Caucasian of European origin-2 & 113 & 5 & 118 & 89 & 34 & 123 \\
\hline Total & 236 & 19 & 255 & 182 & 99 & 281 \\
\hline
\end{tabular}

* Incomplete triads include families with missing parent(s).

"Other Caucasian of European origin-I" included Caucasian triads (excluding French Canadian triads) recruited from Montreal and Ottawa.

"Other Caucasian of European origin-2" included Caucasian triads recruited from Hungary and France. 


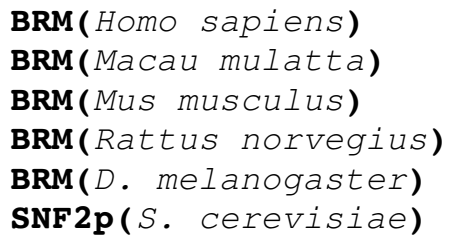

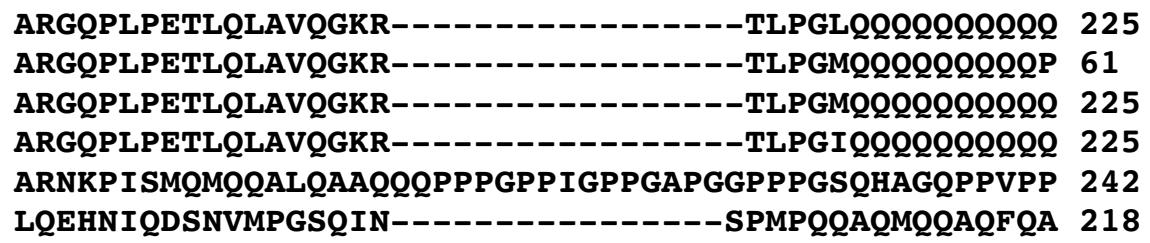

Figure I

CLUSTAL W (I.82) multiple sequence alignment of the polyglutamine domain of mammalian BRM with the $\mathrm{P} / \mathrm{Q}$ rich region in D. melanogaster and S. cerevisiae. Sequence alignment between BRM from Homo sapiens [GenBank: NP 00306I.3], Macau mulatta [GenBank: AAV67666.I], Mus musculus [GenBank: NP_035546.2], Rattus norvegius [GenBank: NP_00I004446.I], D. melanogaster [GenBank: $\underline{\text { 25439] }}$ ] and the homologous SNF2p from S. cerevisiae [GenBank: NP 014933.I] was conducted.

glutamine-rich regions also present in the homologous Drosophila Brahma and Saccharomyces cerevisiae Swi2/ Snf2 proteins (Figure 1). BRM is well conserved with the only known polymorphism within the coding region of the gene (SMARCA2) being a trinucleotide repeat (CAA/ CAG) polymorphism. The most commonly occurring allele, corresponding to 32 trinucleotide repeats ( $181 \mathrm{bps,}$ according to Genotyper ${ }^{\circledR}$ analysis) was designated the "0" allele. The two next most commonly occurring alleles were designated -1 (178 bps) and +1 (184 bps). Rare alleles $-7,-5,+2,+3$, and +4 , having an allele frequency less than 0.01 , were also obtained. Due to the problems that can arise in the cross-tabulation, since these cells had less than 5 cases each, the alleles were grouped for the statistical analyses- alleles -7 , and -5 were grouped with the -1 allele and $+2,+3$, and +4 were grouped with the +1 allele.

Case/control analysis was carried out to compare the allele and genotype frequency of the trinucleotide repeat polymorphism within three Caucasian populations: French Canadian, Tunisian and other Caucasians of European origin. Similar allele and genotype distributions were observed between affected cases and unaffected controls in each of these three populations (Tables 3 and 4 ).

Table 2: Summary of subjects used in the case-control analysis

\begin{tabular}{|c|c|c|c|c|}
\hline & Case & & & Control \\
\hline & Cases included in family-based study* & Isolated casest & Total & \\
\hline French Canadian & 41 & 59 & 100 & 102 \\
\hline Tunisian & 24 & 43 & 67 & 46 \\
\hline Other Caucasian of European origin-I & 58 & 64 & 122 & 125 \\
\hline Total & 123 & 166 & 289 & 273 \\
\hline
\end{tabular}

* Subjects from families having more than one affected individual were not included in the case/control study (please refer to Table I). Only unrelated cases and controls were used for this analysis.

t Isolated cases were those subjects for whom parent DNA samples were not available. 
Table 3: Trinucleotide repeat polymorphism allele frequency, comparing cases and controls within each of the three populations tested

\begin{tabular}{|c|c|c|c|c|c|c|}
\hline \multirow[t]{2}{*}{ Allele } & \multicolumn{2}{|c|}{ French-Canadian } & \multicolumn{2}{|c|}{ Tunisian } & \multicolumn{2}{|c|}{ Caucasian of European origin } \\
\hline & Case $(n=100)$ & Control $(n=102)$ & Case $(n=67)$ & Control $(n=46)$ & Case $(n=122)$ & Control $(n=125)$ \\
\hline-1 & 0.11 & 0.15 & 0.1 & 0.11 & 0.08 & 0.1 \\
\hline 0 & 0.87 & 0.85 & 0.86 & 0.84 & 0.91 & 0.88 \\
\hline \multirow[t]{2}{*}{+1} & 0.03 & 0.01 & 0.04 & 0.05 & 0.01 & 0.02 \\
\hline & \multicolumn{2}{|c|}{$\chi^{2}=3.9, d f=2, p>0.1$} & \multicolumn{2}{|c|}{$\chi^{2}=0.2, d f=2, p>0.5$} & \multicolumn{2}{|c|}{$\chi^{2}=1.29, d f=2, p>0.5$} \\
\hline
\end{tabular}

The alleles in the affected and non-affected populations were in Hardy-Weinberg equilibrium, calculated by considering each allele in combination with every other allele. The family-based association analysis (bi-allelic mode; additive model) showed that none of the alleles were preferentially transmitted/under-transmitted to the affected offspring (Table 5). A minor under-transmission of the -1 allele $(p=0.034)$ was observed. However this effect was not significant when corrected for multiple testing.

These results suggest that there is no association between the trinucleotide repeat polymorphism within SMARCA2 and schizophrenia. Although all subjects included in the study were carefully diagnosed according to DSM criteria, as having schizophrenia or schizoaffective disorder, one cannot exclude the phenotypic diversity that is inherent to the disorder. For example, within our French Canadian group of affected subjects, $70.7 \%$ were diagnosed with paranoid schizophrenia, $5.05 \%$ with the disorganized type, $2.02 \%$ with schizoaffective disorder and $22.22 \%$ with undifferentiated schizophrenia. There has been considerable discussion recently that in studying the genetics of schizophrenia and complex psychiatric disorders, in general, that it is necessary to examine suitable endophenotypes within the disorder rather than to examine the disorder as a whole [17-19]. It remains important therefore to examine the association of this trinucleotide repeat polymorphism within SMARCA2 with specific endophe- notypes resulting from neurodevelopmental deficits, given the importance of BRM in development and neural development in particular. Also given the minor effect detected with the family-based association study, it may be important to re-examine this polymorphism with a larger sample size.

This study also offers a step forward in understanding the polyglutamine domain within BRM. Although BRM has been shown to be important in transcriptional regulation, little is known about the role of the polyglutamine domain. In the populations we have studied, we have not observed an expansion of the trinucleotide repeat region, even though the number of glutamines (32) is close to the pathogenic threshold of 35-40 glutamines [20]. The trinucleotide repeat appears therefore to be stable, though polymorphic. We sequenced the trinucleotide repeat in six individuals, two each being homozygous for the $-1,0$ and +1 alleles. The sequence encoded by this domain, in the 0 allele, is $-\mathbf{Q}_{23}-\mathbf{P}-\mathbf{Q}_{3}-\mathbf{P}_{2}-\mathbf{Q}-\mathbf{P}-\mathbf{Q}-$. The sequence of the - 1 allele was $-\mathrm{Q}_{22}-\mathrm{P}-\mathrm{Q}_{3}-\mathrm{P}_{2}-\mathrm{Q}-\mathrm{P}-\mathrm{Q}$ - while the sequence of the +1 allele was $-\mathrm{Q}_{24}-\mathrm{P}-\mathrm{Q}_{3}-\mathrm{P}_{2}-\mathrm{Q}-\mathrm{P}-\mathrm{Q}-$. It therefore appears that the terminal CAG repeat in the first block of CAA/CAG repeats is the polymorphic site, at least in the individuals studied. This is consistent with results obtained in examining the different alleles at this locus in an Indian population [21]. Further functional studies would be important to assess the role of this polyglutamine domain in protein-DNA and protein-protein

Table 4: Trinucleotide repeat polymorphism genotype frequency, comparing cases and controls within each of the three populations tested

\begin{tabular}{|c|c|c|c|c|c|c|}
\hline \multirow[t]{2}{*}{ Genotype } & \multicolumn{2}{|c|}{ French-Canadian } & \multicolumn{2}{|c|}{ Tunisian } & \multicolumn{2}{|c|}{ Caucasian of European origin } \\
\hline & Case $(n=100)$ & Control $(n=102)$ & Case $(n=67)$ & Control $(n=46)$ & Case $(n=122)$ & Control $(n=125)$ \\
\hline$-1,0$ & 0.21 & 0.25 & 0.19 & 0.2 & 0.15 & 0.18 \\
\hline 0,0 & 0.74 & 0.75 & 0.73 & 0.7 & 0.83 & 0.78 \\
\hline \multirow[t]{2}{*}{$0,+1$} & 0.05 & 0.01 & 0.07 & 0.11 & 0.02 & 0.04 \\
\hline & \multicolumn{2}{|c|}{$\chi^{2}=3.02, d f=2, p>0.1$} & \multicolumn{2}{|c|}{$\chi^{2}=0.4 I, d f=2, p>0.5$} & \multicolumn{2}{|c|}{$\chi^{2}=0.91, d f=2, p>0.5$} \\
\hline
\end{tabular}


Table 5: Transmission Disequilibrium Test and FBAT analysis

\begin{tabular}{ccccc}
\hline Allele & Allele Frequency & No. of informative triads & $Z$ statistic & $p$ \\
\hline-1 & 0.12 & 53 & -2.12 & 0.034 \\
0 & 0.85 & 67 & 1.65 & 0.099 \\
+1 & 0.03 & 23 & 0.35 & 0.72
\end{tabular}

interactions. This may be informative particularly since this domain appears to be a conserved domain in BRM, which itself is a well conserved regulator of transcription.

\section{Conclusion}

Results from our family-based and case-control association study suggest that there is no association between the trinucleotide repeat polymorphism within SMARCA2 and schizophrenia.

\section{Methods \\ Subjects}

Subjects diagnosed with schizophrenia or schizoaffective disorder, their families and unrelated healthy controls were recruited from three populations: Tunisian, French Canadian and other Caucasians of European origin. Patients were diagnosed using DSM-III-R or DSM-IV criteria on the basis of the Diagnostic Interview for Genetic Studies (DIGS) and complementary data from the medical files. Most of these subjects had previously participated in a pharmacogenetic study with a detailed evaluation of therapeutic response to medication [14]. For the familybased study, subjects and their families were recruited from mental health facilities in Montreal, Ottawa, Hungary, France, and Tunisia. A total of 281 complete ( $\mathrm{n}=$ $182)$ and incomplete $(n=99)$ triads were genotyped (Table 1).

Case/control analysis was conducted exclusively with subjects from Montreal, Ottawa and Tunisia since unaffected control subjects were not available for analysis from Hungary and France. This step was undertaken to minimize any effects arising due to population stratification. Unrelated cases $(n=289)$ and controls $(n=273)$ were used for the case-control analysis. The cases included (Table 2): (1) unrelated probands $(\mathrm{n}=123)$, recruited from Montreal, Ottawa, and Tunisia, who were included in the familybased analysis. Only probands from families having one affected individual were included for this case-control analysis (Table 1), in order to avoid introducing bias by selecting between multiple affected individuals from a single family; (2) subjects $(\mathrm{n}=166)$ recruited from mental health facilities in the three regions, for whom parent DNA samples were not available (termed "isolated cases"). Table 2 gives a detailed break-up of the ethnicities of the cases and controls.
Controls were recruited in Montreal, Ottawa and Tunisia, either by newspaper advertisement or random sampling from a downtown population or open advertisement among the employees of the hospitals where the studies were conducted. Each control subject was evaluated by a trained clinician using the Structured Clinical Interview for DSM-IV, Non-patient edition (SCID-NP) to ensure that the individual did not have an ongoing or previous psychiatric illness. Written, informed consent was obtained from each patient and non-affected subject prior to beginning the study. The research protocol and the consent forms were approved by the Ethics Committee of each Institutional Review Board.

\section{Genotyping}

Genomic DNA was extracted from peripheral blood using standard procedures. The trinucleotide repeat within SMARCA2 was amplified by polymerase chain reaction (PCR) using the following primers: forward5'TGCAGTCCAGGGGAAAAGGACGTT3', reverse5'CCCGGGCCAGATGGTCTGTTGTAG3'. The forward primer was fluorescent labeled with 6-FAM ${ }^{\mathrm{TM}}$ (Applied Biosystems). A $15 \mu \mathrm{l} \mathrm{PCR} \mathrm{reaction,} \mathrm{containing} 10$ ng DNA, $2.5 \mathrm{mM} \mathrm{MgCl}_{2}, 0.25 \mathrm{mM}$ of each dNTP, $0.33 \mu \mathrm{M}$ of each primer, and 0.6 units Taq Polymerase was carried out. After initial denaturation at $94^{\circ} \mathrm{C}$ for 5 minutes, 35 cycles were carried out at $94^{\circ} \mathrm{C}$ for $1 \mathrm{~min}, 61.3^{\circ} \mathrm{C}$ for $1 \mathrm{~min}$, $72^{\circ} \mathrm{C}$ for $1 \mathrm{~min}$, followed by a final extension at $72^{\circ} \mathrm{C}$ for $30 \mathrm{~min}$.

After verification of the PCR amplification by agarose gel electrophoresis, $0.5 \mu \mathrm{ls}$ of each sample was mixed with 0.3 $\mu$ ls size standard $\left(\right.$ GeneScan $\left.{ }^{\mathrm{TM}} 500 \mathrm{LIZ}^{\mathrm{TM}}\right)$ and $9.2 \mu \mathrm{ls}$ deionized formamide (Applied Biosystems), denatured at $95^{\circ} \mathrm{C}$ for 5 minutes, and placed on ice. Each 96-well plate was analyzed using the ABI PRISM ${ }^{\circledR} 3100$ Genetic Analyzer and GeneScan v3.7. The sizes of the DNA fragments were obtained in comparison to the DNA standard using Genotyper $^{\circledast}$ Software v3.7. The most frequently occurring allele, corresponding to a size of $181 \mathrm{bp}$ (obtained using Genotyper ${ }^{\circledR}$ ) was designated "0". The sizes of each of the respective alleles increased or decreased proportionately by 3 bps i.e. alleles -1 , and +1 had sizes of 178 and 184 bps respectively.

\section{Statistical analysis}

The Transmission Disequilibrium Test [15] was conducted using the FBAT (Family-Based Association Tests) program [16]. Allele frequencies in affected subjects and non-affected controls were compared using the Pearson chi-square $\left(\chi^{2}\right)$ statistic in Statistica ${ }^{\circledast}$. Statistical significance was established at $p<0.05$. 


\section{Abbreviations \\ BRM - Brahma}

DIGS - Diagnostic Interview for Genetic Studies

FBAT - Family-Based Association Tests

PCR - polymerase chain reaction

SCID-NP - Structured Clinical Interview for DSM-IV, Non-patient edition

SCZ - schizophrenia

SMARC - SWI/SNF-related, matrix-associated, actindependant regulator of chromatin

\section{Authors' contributions}

SS, LX, FF performed the data analysis. SS drafted the manuscript. $\mathrm{CB}, \mathrm{KT}, \mathrm{ZD}, \mathrm{AL}, \mathrm{SL}, \mathrm{MK}, \mathrm{GR}$ and $\mathrm{RJ}$ were involved in the study design and provided clinical support. RJ was responsible for the conception of the study, supervision of the research project and drafting of the manuscript.

\section{Acknowledgements}

SS and LX were supported by a fellowship from the Genes, Environment and Health Training Program at McGill University, funded by Institute of Neurosciences, Mental Health and Addiction/Fonds de la recherche en santé du Quebec. This work was supported by a grant from the Sackler Foundation.

\section{References}

1. Sif S: ATP-dependent nucleosome remodeling complexes: enzymes tailored to deal with chromatin. J Cell Biochem 2004, 91:1087-1098

2. Wang W, Xue Y, Zhou S, Kuo A, Cairns BR, Crabtree GR: Diversity and specialization of mammalian SWI/SNF complexes. Genes Dev 1996, 10:2117-2130.

3. Marshall TW, Link KA, Petre-Draviam CE, Knudsen KE: Differential requirement of SWI/SNF for androgen receptor activity. J Biol Chem 2003, 278:30605-306/3.

4. Kadam S, Emerson BM: Transcriptional specificity of human SWI/SNF BRGI and BRM chromatin remodeling complexes. Mol Cell 2003, I I:377-389.

5. Reyes JC, Barra J, Muchardt C, Camus A, Babinet C, Yaniv M: Altered control of cellular proliferation in the absence of mammalian brahma (SNF2alpha). EMBO J 1998, 17:6979-91.

6. Hakak Y, Walker JR, Li C, Wong WH, Davis KL, Buxbaum JD, Haroutunian V, Fienberg AA: Genome-wide expression analysis reveals dysregulation of myelination-related genes in chronic schizophrenia. Proc Natl Acad Sci USA 200I, 98:4746-475।

7. Hemby SE, Ginsberg SD, Brunk B, Arnold SE, Trojanowski JQ, Eberwine $J \mathrm{H}$ : Gene expression profile for schizophrenia: discrete neuron transcription patterns in the entorhinal cortex. Arch Gen Psych 2002, 59:631-640.

8. Holstege FC, Jennings EG, Wyrick JJ, Lee TI, Hengartner CJ, Green MR, Golub TR, Lander ES, Young RA: Dissecting the regulatory circuitry of a eukaryotic genome. Cell 1998, 95:717-728.

9. Sudarsanam P, lyer VR, Brown PO, Winston F: Whole-genome expression analysis of snf/swi mutants of Saccharomyces cerevisiae. Proc Natl Acad Sci USA 2000, 97:3364-3369.
10. McGrath J], Feron FP, Burne TH, Mackay-Sim A, Eyles DW: The neurodevelopmental hypothesis of schizophrenia: a review of recent developments. Ann Med 2003, 35:86-93.

II. Machida Y, Murai K, Miyake K, lijima S: Expression of chromatin remodeling factors during neural differentiation. J Biochem (Tokyo) 200I, I 29:43-49.

12. Kondo T, Raff M: Chromatin remodeling and histone modification in the conversion of oligodendrocyte precursors to neural stem cells. Genes Dev 2004, 18:2963-2972.

13. Segurado R, Detera-Wadleigh SD, Levinson DF, Lewis CM, Gill M, Nurnberger JI Jr, Craddock N, DePaulo JR, Baron M, Gershon ES, Ekholm J. Cichon S, Turecki G, Claes S, Kelsoe JR, Schofield PR, Badenhop RF, Morissette J, Coon H, Blackwood D, Mclnnes LA, Foroud T, Edenberg HJ, Reich T, Rice JP, Goate A, Mclnnis MG, McMahon FJ, Badner JA, Goldin LR, Bennett P, Willour VL, Zandi PP, Liu J, Gilliam C, Juo SH, Berrettini WH, Yoshikawa T, Peltonen L, Lonnqvist J, Nothen MM, Schumacher J, Windemuth C, Rietschel M, Propping P, Maier W, Alda M, Grof P, Rouleau GA, Del-Favero J, Van Broeckhoven C, Mendlewicz J, Adolfsson R, Spence MA, Luebbert H, Adams LJ, Donald JA, Mitchell PB, Barden N, Shink E, Byerley W, Muir W, Visscher PM, Macgregor S, Gurling H, Kalsi G, McQuillin A, Escamilla MA, Reus VI, Leon P, Freimer NB, Ewald H, Kruse TA, Mors $O$, Radhakrishna U, Blouin JL, Antonarakis SE, Akarsu N: Genome scan meta-analysis of schizophrenia and bipolar disorder, part III: Bipolar disorder. Am J Hum Genet 2003, 73:49-62.

14. Joober R, Rouleau GA, Lal S, Dixon M, O'Driscoll G, Palmour R, Annable L, Bloom D, Lalonde P, Labelle A, Benkelfat C: Neuropsychological impairments in neuroleptic-responder vs. -nonresponder schizophrenic patients and healthy volunteers. Schizophr Res 2002, 53:229-238.

15. Spielman RS, McGinnis RE, Ewens W]: Transmission test for linkage disequilibrium: the insulin gene region and insulindependent diabetes mellitus (IDDM). Am J Hum Genet 1993, 52:506-5I6.

16. Laird NM, Horvath S, Xu X: Implementing a unified approach to family-based tests of association. Genet Epidemiol 2000, 1 9(SuppI I):S36-42

17. Hallmayer JF, Kalaydjieva L, Badcock J, Dragovic M, Howell S, Michie PT, Rock D, Vile D, Williams R, Corder EH, Hollingsworth K, Jablensky A: Genetic evidence for a distinct subtype of schizophrenia characterized by pervasive cognitive deficit. Am J Hum Genet 2005, 77:468-476.

18. Weiser M, van Os ], Davidson M: Time for a shift in focus in schizophrenia: from narrow phenotypes to broad endophenotypes. Br J Psych 2005, 187:203-205.

19. Gottesman II, Gould TD: The endophenotype concept in psychiatry: etymology and strategic intentions. Am J Psych 2003 , 160:636-645.

20. Cummings CJ, Zoghbi HY: Trinucleotide repeats: Mechanisms and pathology. Annu Rev Genomics Hum Genet 2000, I:28I-328.

21. Pandey N, Mittal U, Srivastava AK, Mukerji M: SMARCA2 and THAPII: potential candidates for polyglutamine disorders as evidenced from polymorphism and protein-folding simulation studies. J Hum Genet 2004, 49:596-602.

Publish with Bio Med Central and every scientist can read your work free of charge

"BioMed Central will be the most significant development for disseminating the results of biomedical research in our lifetime. "

Sir Paul Nurse, Cancer Research UK

Your research papers will be:

- available free of charge to the entire biomedical community

- peer reviewed and published immediately upon acceptance

- cited in PubMed and archived on PubMed Central

- yours - you keep the copyright
BioMedcentral 